\title{
Resource-Use Efficiency of Honey Production in Kachia Local Government Area, Kaduna-State, Nigeria
}

\author{
Ahmad,* Olohungbebe, S (Corresponding Author) \\ Department of Agricultural Economics and Extension, Faculty of Agriculture, \\ University of Abuja, PMB 117, Gwagwalada, Abuja, Nigeria.osahmad787@gmail.com \\ Alabi, Olugbenga. $\mathrm{O}(\mathrm{PhD})$ \\ Department of Agricultural Economics and Extension, Faculty of Agriculture, \\ University of Abuja, PMB 117, Gwagwalada, Abuja, Nigeria. \\ Daniel, P. O. \\ Department of Agricultural Economics and Extension, Faculty of Agriculture, \\ University of Abuja, PMB 117, Gwagwalada, Abuja, Nigeria.
}

Received: December 4, 2015 Accepted: December 24, 2015 Published: December 28, 2015 doi:10.5296/jas.v4i1.8790

URL: http://dx.doi.org/10.5296/jas.v4i1.8790

\begin{abstract}
This study examined resource-use efficiency of honey production in Kachia Local Government Area, Kaduna, Nigeria. The primary data used for the investigation were obtained using structured questionnaires administered to 50 producers. The data were analysed using descriptive statistics, farm budget techniques, multiple regression analysis and resource-use efficiency. Multiple regression analysis used to examine factors influencing output of honey in the study area revealed that the coefficient of multiple determinations $\left(\mathrm{R}^{2}\right)$ of 0.59 which implies that $59 \%$ of the dependent variable in the model was explained by the independent variables included in the model. Number of bee hives was significant at $(\mathrm{p}<$ 0.01).Estimated resource use efficiency revealed that number of bee hives and family labours were underutilized. This study concluded that the bee farmers in the study area should be given adequate training on rudiments of beekeeping.
\end{abstract}

Keywords: Resource-Use Efficiency, Honey Production, Kaduna State, Nigeria.

\section{Introduction}

In recent years, the production of honey through beekeeping is becoming popular among the small scale farmers. This is due to the fact that the farmers have resorted to the need for 
income in diverse ways; thereby reducing the risk involved in depending on conventional crop and animal production as the only source of income (Olarinde et al, 2008). Apiculture is an aspect of the agricultural sector that has not been given much attention particularly at the commercial level in the country (ICTA, 2004). Modern beekeeping is undertaken because it serves as a source of food, employment and income (Olagunju and Adejumobi, 2003). Beekeeping for honey production has been identified as one of the most lucrative enterprise in many parts of the World. In United States of America, about 109,799,366.60 Kg of honey worth $\$ 24,200,00.00$ is produced each year; the same goes to the former USSR. Australia produces $18,375,00051 \mathrm{Kg}$ of honey and exports $5,898,313.08 \mathrm{Kg}$ of it worth 900,000 pounds, and Tanzania about 750,000 pounds worth of honey produce annually (Canadian Statistics, 2003). Presently in Nigeria, honey production is still at its developmental stage, though its awareness was created for back early 1950s. This could be attributed to inefficient and inadequate information on the enterprise and the belief that swarms of bees are a taboo and signifies that a terrible mayhem is about to befall the individual whom it visits (Oyekuru, 2004). Generally, honey production enterprise attracts the attention of a greater percentage of the populace these days because of its profitability and it is a visible complementary activity for rural people and requires very little investments and in addition, produces quick returns (Onyekuru, 2004).The demand for bee honey in Nigeria is on the increase, but organized beekeeping as an enterprise is low (Eluagu and Nwani, 1999). ). In most parts of Africa it is used for brewing honey beer and to a much lesser degree, as medicine; honey provides a valuable food when it is consumed in its unprocessed state, i.e. liquid, crystallized or in the comb. In these forms it is taken as medicine, eaten as food or incorporated as an ingredient in various food recipes (Olstrom, 1983). Also, in addition to the thousands of "home-made" recipes in each cultural tradition, honey is largely used on a small scale, as well as, at an industrial level in baked products, confectionary, candy, marmalades, jams, spreads, breakfast cereals, beverages, milk products and many preserved products (Olstrom, 1983). The broad objective of the study is to evaluate the resource-use efficiencies of honey production in Kachia Local Government Area, Kaduna State, Nigeria. The specific objectives are to:(i) examine the socio-economic characteristics of honey producers in the study area, (ii) estimate the costs and returns of honey production in the study area, (iii) evaluate resource-use efficiency of honey production in the study area.

\section{Methodology}

\subsection{The Study Area}

The study was undertaken in Kaduna metropolis. Kaduna State is located in the mid-central portion of the Northern parts of Nigeria, approximately between Latitudes $10^{0} 20 \mathrm{~N}$ and Longitudes $7^{0} 45^{\prime} \mathrm{E}$ and covers an area of 45, 71.2 Square Kilometres. It has a population of 6,113503 (2006 census figures) and a population density of 130 people per Square Kilometre. It accounts for $4.3 \%$ of Nigeria's total population. The mean annual rainfall in the southern part (in places like Kafanchan and Kagoro) is $1,1016 \mathrm{~mm}$. The State experiences a tropical continental climate with two distinct seasonal climates, dry and rainy seasons. The wet season (May to October) is heavier in the southern part of the state than the northern part. Agriculture constitutes the largest occupation of the people with many citizens participating 
in small scale farming. The State is a major region of animal husbandry. Major foods and cash crops produced in the State includes, cotton, groundnut, guinea corn, millet, ginger, tobacco, beans etc. (www.google.com).

\subsection{Sampling Technique and Sample Size}

For the purpose of this study, two communities were visited in Kachia Local Government Area in Kaduna State, specifically Katari and Azara Areas of the State. Simple random sampling technique was used for this study. Twenty-five (25) respondents were randomly selected from each of the villages giving a total sample size of fifty (50) respondents.

\subsection{Method of Data Collection}

The data used for this study consist mainly of primary data. Data were obtained through the use of questionnaire. The questionnaire was used to collect information on the socio-economic variable of the beekeepers, their management practices, the cost incurred, their income, revenue, efficiency and production data. The interview was carried out during their group meeting. The survey was carried out in 2014 production season. The production cycle as stated by the beekeepers take place within a year (9-12 months).

\subsection{Methods of Data Analysis}

The analytical tools that were used in this study to achieve stated objectives include the following:

(i) Descriptive Statistics

(ii)Farm Budgeting Technique

(iii) Multiple Regression Analysis

(iv) Resource-Use Efficiency

\subsubsection{Descriptive Statistics}

This analytical tool was used to examine the socio-economic characteristics of honey producers which include; their gender, marital status, household size, age, level of education etc. Statistical package for Social Science (SPSS) was used. Descriptive statistics involve the use of mean, frequency distribution tables, percentages etc. This was used to achieve objective one (1).

\subsubsection{Farm Budgeting Technique}

Costs incurred and returns in honey and beeswax production were estimated based on prevailing market price. Costs of production include; raw materials such as bucket, container; expenses on land (rent or lease); labour (wages) etc.

The Net Farm Income (NFI) is calculated thus:

\section{NFI=TR-TC}

Where, NFI = Net Farm Income ( $)$ 
$\mathrm{TR}=$ Total Revenue from Honey and other Hive Products

$$
\begin{gathered}
\mathrm{TC}=\mathrm{TFC}+\mathrm{TVC} \\
\mathrm{TR}=\mathrm{P} . \mathrm{Q}
\end{gathered}
$$

Where, $\mathrm{P}=$ Price of honey produced in Naira per Litre.

$\mathrm{Q}=$ Output of honey produced in Litre

This was be used to achieve specific objective two.

\subsubsection{Multiple Regression Analysis}

The model is implicitly stated as:

$$
\mathrm{Y}=\mathrm{f}\left(\mathrm{X}_{1}, \mathrm{X}_{2}, \mathrm{X}_{3}, \mathrm{X}_{4}, \mathrm{U}_{\mathrm{i}}\right)
$$

Where,

$\mathrm{Y}=$ Output of Honey Produced (Litres)

$X_{1}=$ Number of Hives set by the Beekeeper (Units)

$\mathrm{X}_{2}=$ Hired Labor (Mandays)

$\mathrm{X}_{3}=$ Family Labour (Mandays)

$\mathrm{X}_{4}=$ Cost of Bating Materials (Naira)

$\mathrm{Ui}=$ Random Error Term/Disturbance Error Term.

Explicitly, the functions are stated as:

$\mathrm{Y}=\mathrm{a}+\mathrm{bX} \mathrm{X}_{1}+\mathrm{CX}_{2}+\mathrm{dX}_{3}+\mathrm{eX}_{4}+\mathrm{Ui}$ (Linear)

$\log Y=a+b \log X_{1}+\operatorname{cLog} X_{2}+d \log X_{3}+e \log X_{4}+$ Ui (Double-Log)

$\mathrm{Y}=\mathrm{a}+\mathrm{bLog} \mathrm{X}_{1}+\mathrm{cLog} \mathrm{X}_{2}+\mathrm{dLog} \mathrm{X}_{3}+\mathrm{eLog} \mathrm{X}_{4}+\mathrm{Ui}($ Semi-Log).

This was used to achieve objective two (2).

\subsubsection{Resource-Use Efficiency}

Resource-Use Efficiency of honey production was estimated using the formula,

$$
\frac{\mathrm{MVP}}{\mathrm{MFC}}=\mathrm{r}
$$

Where,

$$
\begin{aligned}
& \text { MVP = Marginal Value Product } \\
& \text { MFC = Marginal Factor Costs ( }) \\
& \text { r= Resource-Use Efficiency of Honey Production. }
\end{aligned}
$$

If $r=1$, it indicates that the resource-use efficiency of honey production is utilized. 
If $r>1$, it indicates that the resource-use honey production is underutilized.

If $\mathrm{r}<1$, it indicates that the resource-use efficiency of honey production is over utilized.

$$
\mathrm{MVP}=\mathrm{MPP} \times \mathrm{Pq}
$$

Where,

MPP = Marginal Physical Product

$\mathrm{Pq}=$ Price of Unit Output ( $)$

This was used to achieve objective three (3).

\section{Results and Discussion}

Table 1 show that ninety (90) percent of honey producers in the study area were male, thus confirming the notion that bee keeping is a hazardous occupation, and about ten (10) percent of the beekeepers were women (Babatunde et al, 2007). Furthermore, seventy-eight (78) percent of honey producers were married. Most of the respondents were educated (Lawal, 2002). Sixteen (16) percent of honey producers were single, four (4) percent were widow and only two (2) percent were widower. About ninety (90) percent of honey producers had less than 10 members as household. This is in line with finding of Mbah (2012) who opined that beekeepers rely so much on household labour for beekeeping activities. However, under subsistence agriculture, much reliance is often placed on the strength of household to supply the much need farm labour in the absence of mechanized equipment. Thus, the larger the household size, the higher the supply of household labour. Also, about ten (10) percent had between 11-20 members of household size who worked on the farm of honey. Honey producers in the study area are middle-aged. About eighty-eight (88) percent of honey producers were less than fifty (50) years of age, which means they are still in their active productive age, which signifies increase in the output of honey as also observed by Mbah (2012). The study also revealed that twelve (12) percent of honey producers are between fifty-one (51) and seventy (70) years of age. The results further showed that majority (42 percent) of honey producers in the study area are into farming, and sixteen (16) percent are civil servants. This corroborates with the views of Folayan et al (2013) that the both (farmers and civil servants) diversify into honey production to ensure optimum and continuous flow of income. This study further shows that students (10 percent) are among honey producers in the study area. Furthermore almost all the beekeepers in the study area are literate. About ninety -eight (98) percent of honey producers had formal education. This implies that beekeeping is practiced mostly by educated people and therefore, adoption of modern beekeeping techniques would not be a problem. Studies have shown that education is positively related to adoption of innovation (Balogun, 2000). Nevertheless, only two (2) percent of the honey producers had non-formal education. Also, about ninety (90) percent of honey producers had less than 20 years of experience in honey production. This is in line with finding of Tijani et al (2011) who observed that the higher the numbers of years spend in farming by a farmer, the more he becomes aware of new production techniques, thereby increasing the level of productivity. The results of the farm budgeting analysis are presented in 


\section{$\triangle$ Macrothink}

Table 2. Costs incurred on various resources used and profits obtained from the sale of the produce were estimated based on the market price at the period under consideration 2014 family season. The gross income was calculated by multiplying the total quantity of honey produced by the price of output sold. The gross income of the honey producers was $\$ 363,672$. The total cost was put into consideration by adding the total variable costs which was $\$ 50071.49$ and the total fixed cost was $\$ 153259.73$ which gave the total cost of $\$ 6,953,820$. The total variable costs include: cost of land cleaning, cost of bating materials, cost of chemical, cost of hired labour, and cost of family labour to mention a few. Also, total fixed cost include: cost of uniform, cost of boot, cost of container etc. The net income was estimated to be 17,980,268.78. The factors influencing output of honey produced were expressed in the econometric multiple regression analysis Table 3 . The variables examined in the model include; number of hives (colony) $\mathrm{X}_{1}$; hired labour (mandays) $\mathrm{X}_{2}$; family labour (mandays) $\mathrm{X}_{3}$; and cost of bating materials $(\mathrm{N}) \mathrm{X}_{4}$. Double-log functional form was selected as the lead equation. In the lead equation, numbers of hives $\mathrm{X}_{1}$ were significant at $1 \%$ probability level. The coefficient of multiple determinations $\left(\mathrm{R}^{2}\right)$ is 0.529 . This implies that 52.95 of variations in the dependent variable were explained by variations in the explanatory variables included in the model. An estimate obtained from the double-log functional form is direct elastics. For instance, the estimated coefficient for number of hives was 0.895 . This implies that if numbers of hives are increased by $1 \%$ holding other variable constant, the output of honey produced will increase by 0.895 . Estimated resource use efficiency shows that number of bee hives $\left(\mathrm{X}_{1}\right)$ and family labour $\left(\mathrm{X}_{4}\right)$ are underutilized (Table 4$)$.

Table 1. Socio-Economic Characteristics of Honey Producers in Kachia Local Government Area, Kaduna State.

\begin{tabular}{|l|l|l|}
\hline Variable & Frequency & Percentage (\%) \\
\hline Sex & \multicolumn{2}{l|}{} \\
\hline Male & 45 & 90.00 \\
\hline Female & 05 & 10.00 \\
\hline Marital Status & 39 & 78.00 \\
\hline Married & 08 & 16.00 \\
\hline Single & 02 & 04.00 \\
\hline Widow & 01 & 02.00 \\
\hline Widower & \multicolumn{2}{l|}{} \\
\hline Household Size & 45 & 90.00 \\
\hline $1-10$ & 05 & 10.00 \\
\hline $11-20$ & \multicolumn{2}{l|}{} \\
\hline Age (Years) & 09 & 18.00 \\
\hline $21-30$ & 15 & 30.00 \\
\hline $31-40$ & 20 & 40.00 \\
\hline $41-50$ & 04 & 08.00 \\
\hline $51-60$ &
\end{tabular}




\begin{tabular}{|c|c|c|}
\hline $61-70$ & 02 & 04.00 \\
\hline \multicolumn{3}{|l|}{ Major Occupation } \\
\hline Farming & 21 & 42.00 \\
\hline Civil servant & 08 & 16.00 \\
\hline Business & 03 & 06.00 \\
\hline Caterpillar mechanic & 01 & 02.00 \\
\hline Honey producers \& Business & 04 & 08.00 \\
\hline Farming and business & 01 & 02.00 \\
\hline Honey producers \& Farming & 03 & 06.00 \\
\hline Clergy & 01 & 02.00 \\
\hline Mason & 01 & 02.00 \\
\hline Student & 05 & 10.00 \\
\hline Student and Business & 01 & 02.00 \\
\hline Honey producer & 01 & 02.00 \\
\hline \multicolumn{3}{|l|}{ Mode of Honey Production } \\
\hline Full - Time & 33 & 66.00 \\
\hline Part - Time & 17 & 34.00 \\
\hline \multicolumn{3}{|l|}{ Education Level } \\
\hline Primary & 09 & 18.00 \\
\hline Secondary & 19 & 38.00 \\
\hline Tertiary & 21 & 42.00 \\
\hline Non- Formal & 01 & 02.00 \\
\hline \multicolumn{3}{|c|}{ Experience of Honey Production (Years) } \\
\hline $1-10$ & 25 & 50.00 \\
\hline $11-20$ & 20 & 40.00 \\
\hline $21-30$ & 03 & 06.00 \\
\hline $31-40$ & 02 & 04.00 \\
\hline Total & 50 & 100.00 \\
\hline
\end{tabular}

Source:-Field Survey, 2014.

Farm Budget Technique

Table 2. Costs and Returns Analysis of Honey Production in the Study Area.

\begin{tabular}{|c|l|l|}
\hline & Items & Mean value (N) \\
\hline A & Variable Cost & \\
\hline (i) & Cost of Land Clearing & $15,636,36.00$ \\
\hline (ii) & Cost of Bating Material & $2,654.00$ \\
\hline (iii) & Cost of Chemical (Additive) & 410.00 \\
\hline (iv) & Cost of Labour (Hired) & $3,525.00$ \\
\hline
\end{tabular}




\begin{tabular}{|c|l|l|}
\hline (v) & Labour Cost of Children & $2,519.05$ \\
\hline (vi) & Labour Cost of Women & $2,645.83$ \\
\hline (vii) & Rentage Cost of Land & $22,681.25$ \\
\hline (B) & Total Variable Cost & $\mathbf{5 0 , 0 7 1 . 4 9}$ \\
\hline (C) & Fixed Cost & \\
\hline (i) & Cost of Hive & $30,491.53$ \\
\hline (ii) & Cost of Uniform & $14,157.14$ \\
\hline (iii) & Cost of Boot & $7,418.75$ \\
\hline (iv) & Cost of Machete & $4,296.88$ \\
\hline (v) & Cost of Basin & $13,903.45$ \\
\hline (vi) & Cost of Wheelbarrow/Motorbike & $36,903.45$ \\
\hline (vii) & Cost of Container & $27,501.00$ \\
\hline (viii) & Cost of Bucket & $8,503.19$ \\
\hline (ix) & Cost of Plastic Bowl & $20,060.71$ \\
\hline (D) & Total Fixed Cost & $\mathbf{1 5 3 , 2 5 9 . 7 3}$ \\
\hline & Total Cost (B + D) & $\mathbf{2 0 3 , 3 3 3 . 2 2}$ \\
\hline & Gross Income & $\mathbf{1 7 , 9 8 0 , 2 6 8 . 7 8}$ \\
\hline & Net Income & \\
\hline
\end{tabular}

Source: - Field Survey, 2014.

Multiple Regressions Analysis

Table 3. Multiple Regressions Analysis (Double Equation as Lead Equation)

\begin{tabular}{|l|l|l|l|}
\hline Variables & $\begin{array}{l}\text { Regression } \\
\text { Coefficient }\end{array}$ & $\begin{array}{l}\text { Standard } \\
\text { Error }\end{array}$ & t-value \\
\hline Constant & 3.279 & 0.928 & 3.532 \\
\hline $\begin{array}{l}\mathrm{X}_{1} \text { (Number of Bee } \\
\text { Hives) }\end{array}$ & 0.895 & 0.130 & $6.867 * * *$ \\
\hline $\mathrm{X}_{2}$ (Hired Labour) & -0.257 & 0.201 & -1.277 \\
\hline $\mathrm{X}_{3}$ (Family Labour) & 0.053 & 0.229 & 0.232 \\
\hline $\begin{array}{l}\mathrm{X}_{4} \text { (Cost of Bating } \\
\text { Material) }\end{array}$ & -0.014 & 0.120 & -1.116 \\
\hline $\mathrm{R}^{2}$ Value & 0.529 & & \\
\hline Adjusted R Value & 0.487 & & \\
\hline $\mathrm{F}-$ Value & $12.615^{* * *}$ & & \\
\hline
\end{tabular}

Source- Field Survey, 2014. 
Table 4. Estimated Resource- Use Efficiency of Honey Production in the Study Area.

\begin{tabular}{|l|c|c|c|c|}
\hline Resource & MPP & MVP & MFC & $\begin{array}{l}\text { Allocative } \\
\text { Efficiency (r) }\end{array}$ \\
\hline Number of Bee Hives $\left(\mathrm{X}_{1}\right)$ & 15.59 & 11310.55 & 725.5 & 15.59 \\
\hline Hired Labour $\left(\mathrm{X}_{2}\right)$ & $\begin{array}{l}-118.9 \\
8\end{array}$ & -86319.04 & 725.5 & -118.98 \\
\hline Family Labour $\left(\mathrm{X}_{3}\right)$ & 135.27 & 98138.39 & 725.5 & 135.27 \\
\hline Cost of Bating Material $\left(\mathrm{X}_{4}\right)$ & -0.009 & -6.66 & 725.5 & -0.009 \\
\hline
\end{tabular}

Source: Field Survey, 2014

\section{Conclusion and Recommendations}

The study revealed that the honey production in the study area is a viable and profitable enterprise. Based on the results, the following recommendations are made: the farmers in the study area should be given adequate training on rudiments of beekeeping. This will ensure proper understanding of modern equipment and adopt technology capable of increasing not only the profitability of the enterprise but also make efficient use of bee resources. Establishment of bee farmers' cooperation association for annexing financial aids, marketing information and inputs from government and non-government organisations .Creating a market channel that will take care of commensurate price for product of new beekeeping enterprise .Government at all levels should endeavour to stimulate farmers to boost honey production by providing and subsidise if need be, necessary infrastructures and enabling environment which provide impetus that will ease people transition from traditional to modern beekeeping easy.

\section{References}

Babatunde, R. O., Olorunsanya, E. O., Omotesho, O. A., \& Alao, B. I. (2007). Economic of Honey Production in Nigeria: Implications for Poverty Reduction and Rural Development, Global Approaches to Extension Practice (GAEP), 3(2).

Balogun, A. L. (2000). Adoption of Alley Farming Among the Farmers in Osun State, Nigeria. Unpublished Ph.D Thesis, Obafemi Awolowo University, Ile-Ife, Nigeria, 291.

Canadian Statistics (2003). Honey production, (2003). Canadian Bee Journal, 35(4), 61-72.

Eluagu, L. S., \& Nwani, L. N. (1999). An Economic Appraisal of an Improved Method of Beekeeping in Nigeria. A case study of Apiculture unit, Federal College of Agriculture, Umudike. The Nigerian Agricultural Journal, 6(2), 90-105.

ERLS (1995).Bee keeping Technologies for Nigerian Farmers. Extension Bulletin. Ahmadu Bello Univeristy, Zaria. Nigeria. 


\section{Al Macrothink}

Journal of Agricultural Studies

ISSN 2166-0379

2016, Vol. 4, No. 1

Folayan, J. A., \& Bifarin, J. O. (2013). Profitability Analysis of Honey Production in Edo North Local Government of Area of Edo State, Nigeria. Journal ofAgricultural Economics and Development, 2(2), 60-64.

ICTA (2004). The Prospect of Beekeeping in the Modern World. Paper Delivered at Training The Trainers State Organized Workshop for Officials of L.G. As, held between $11^{\text {th }}-14^{\text {th }}$ March, 2003, at the Federal College of Forestry Mechanization, Afaka, Kaduna, P4. International Centre for Tropical Apiculture, 2004.

Lawal, W. L., \& Ibebulem, U. O., \& Ajani, O. I. (2002). Resource-Use Efficiency in Apiculture in Umuahia-North Local Government, Abia State, Nigeria.

Mbah, S. O. (2012). Profitability of Honey Production Enterprise in Umuahia Agricultural Zone of Abia State, Nigeria Int'l Journal of Agric and Rural Development.

Olagunju, F. I., \& Ajetumobi, J. O. (2003). Profitability of Honey Production under Improved Method of Beekeeping in Oyo State, Nigeria. International Journal of Economics and Development, 3(1), 148-151.

Olarinde, L., Ajao, O., \& Okunola, S. O. (2008): Determinants of Technical Efficiency in Beekeeping Farms in Oyo State, Nigeria: A Stochastic Production Frontier Approach. Research Journal of Agriculture and Biological Sciences, INSI Net Publication.

Olstrom, J. M. (1983). Dried honey. Am. Bee J. 123, 656-659.

Onyekuru, N. A. (2004). " Economics Analysis of Honey Production in Nsukka, L. G. A. of Enugu State. Unpublished B.Sc. Degree Thesis, Department of Agricultural Economics University, Nsukka.

Tijani B. A., Ala, A. L. Maikasuwa, M. A., \& Ganawa, N. (2011) Economic Analysis of Beekeeping in Chibok Local Government Area of Borno State, Nigeria. Nigeria Journal of Basic and Applied Science (2011) ISS 079498.www.google.com [accessed 23/07/2014].

\section{Copyright Disclaimer}

Copyright for this article is retained by the author(s), with first publication rights granted to the journal.

This is an open-access article distributed under the terms and conditions of the Creative Commons Attribution license (http://creativecommons.org/licenses/by/3.0/). 